\title{
CONTROL PLATE FRICTION TEST \\ (EML-14)
}

\author{
Westinghouse Electric Corporation \\ Astronuclear Laboratory \\ P. O. Box 10864 \\ Pittsburgh, Pennsylvania 15236
}

PREPARED BY:
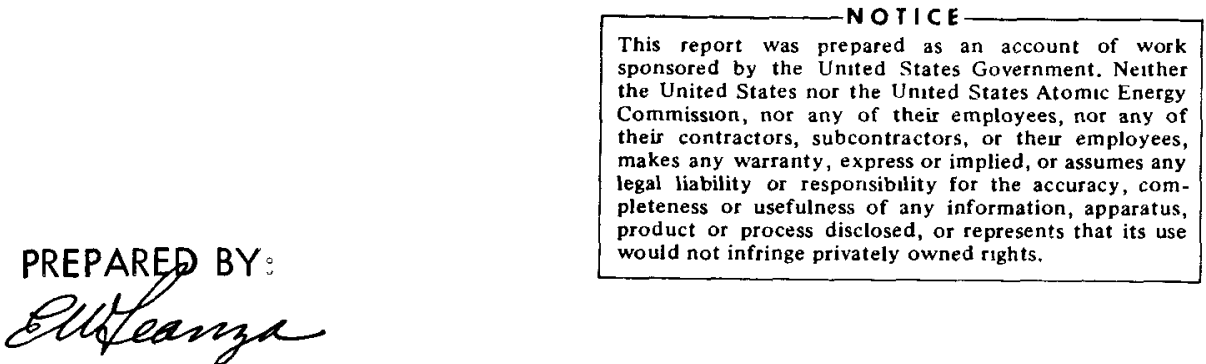

E. W. Leanza

Support Structure \& Cryogenic Experiments

APPROVED BY:

11. J. Bufano

N. J.Bifand, Supervisor

Suppgrt Structure \& Cryogenic Experiments

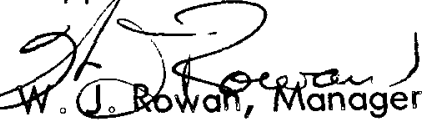

Engineering Mechanics

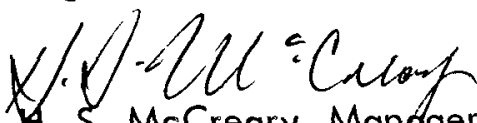

4. S. McCreary, Manáger

INFORMATION CATEGORY

Experimental Engineering

31: \% j:

W. G. Roman, Manager

Reactor Engineering, NERVA Project

$/$ fep

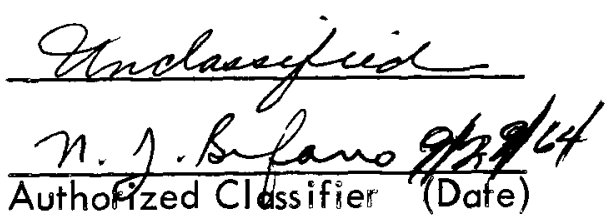




\section{DISCLAIMER}

This report was prepared as an account of work sponsored by an agency of the United States Government. Neither the United States Government nor any agency Thereof, nor any of their employees, makes any warranty, express or implied, or assumes any legal liability or responsibility for the accuracy, completeness, or usefulness of any information, apparatus, product, or process disclosed, or represents that its use would not infringe privately owned rights. Reference herein to any specific commercial product, process, or service by trade name, trademark, manufacturer, or otherwise does not necessarily constitute or imply its endorsement, recommendation, or favoring by the United States Government or any agency thereof. The views and opinions of authors expressed herein do not necessarily state or reflect those of the United States Government or any agency thereof. 


\section{DISCLAIMER}

Portions of this document may be illegible in electronic image products. Images are produced from the best available original document. 
TABLE OF CONTENTS

\begin{tabular}{|c|c|c|}
\hline & & Page \\
\hline & List of Figures & $\mathrm{i}$ \\
\hline 1.0 & Summary & 1 \\
\hline 2.0 & Introduction & 1 \\
\hline 3.0 & Test Description & 1 \\
\hline 4.0 & Results & 3 \\
\hline 5.0 & Conclusions & 3 \\
\hline & Figures & 4 \\
\hline & LIST OF FIGURES & \\
\hline Number & Title & Page \\
\hline 1 & Control Drum Poison Plate Friction Test Rig & 4 \\
\hline 2 & Control Plate Friction Test Setup & 5 \\
\hline 3 & $\begin{array}{l}\text { Control Plate Assembly Showing Spacer Shims Under } \\
\text { Rivet Collars }\end{array}$ & 6 \\
\hline
\end{tabular}




\subsection{SUMMARY}

Fyiction tests were performed to determine the force required to slip a control plate between the control drum beryllium cylinder and the aluminum drum housing. Tests were conducted at ambient temperature and at $140^{\circ} \mathrm{R}$ with the control drum in the "as assembled" condition and reworked to simulate nominal tolerance conditions

The force required to move the control plate in the "as assembled" condition was $12.6 \mathrm{lb}$ at ambent temperature and $42.6 \mathrm{lb}$ at $140^{\circ} \mathrm{R}$. With the control drum in the reworked condition, the slip forces at room temperature and $140^{\circ} \mathrm{R}$ were found to be 48.7 and $1128 \mathrm{lb}$, respectively.

\section{$2,0 \quad$ INTRODUCTION}

In preparation for the NRX-A2 and A3 reactor tests, one problem area considered was the possibility of control plate failure due to friction loads on the control plate arising from differential thermal contractions between the control plate and the other drum components in contact with it. Fragments resulting from a plate failure could cause jamming of the $d$ rum and clogging of the drum coolant passages Since it was difficult to predict the friction forces, it was decided to determine these forces experumentally

\subsection{TEST DESCRIPTION}

The tests were performed in the control dru $m$ test rig as shown schematically in Figure 1.

The dome end bearing shaft cap was removed from the drum assembly and the pin attaching the end control plate to the beryllium cylinder was removed. Load 
fitting straps were attached to the control plate so that the plate could be pulled by means of a cable. The control drum assembly was then placed in the control drum environmental test chamber. The chamber supported the control drum in a vertical position. A wooden block, made to fit the bottom of the chamber, contained a hule to position the nozzle end shaft of the control drum. The upper end of the control drum beryllium cylinder was positioned with screws attached to a support bolted across the opening of the test chamber. The cable, attached to the control plate pulling fitting, was oriented vertically until it engaged a pulley which changed the cable direction $75^{\circ}$ to a horizontal position. The opposite end of the cable was pulled by the output shaft of a motor driven speed reducer.

A load cell, located between the pulley and control plate (see Figure 2), was used in conjunction with an $X-Y$ recorder to obtain the friction forces developed in moving the contsol plate during the tests. A $100 \mathrm{lb}$ capacity load cell was used for the room temperature tests while a $2000 \mathrm{lb}$ capacity load cell was used for the cryogenic temperature tests.

For the cryogenic temperature test, the environmental test chamber was filled with liquid nitrogen, and the drum components were allowed to attain the temperature of the liquid nitrogen before friction measurements were made. This test approximated the most severe differential thermal contractions expected between the control plate and adjacent drum components during reactor operation.

Following friction tests with the control drum in the "as assembled" condition, tests were performed simulating a nominal combination of control drum tolerances. 


\subsection{RESULTS}

In the first test performed with the control drum in the "as assembled" condition, forces of $12.6 \mathrm{lb}$ at room temperature and $42.6 \mathrm{lb}$ at liquid nitrogen temperature were required to move the control plate between the beryllium cylinder and aluminum housing In the second test performed with the reworked control plate assembly representing a nominal combination of tolerances, the results indicated friction forces of $48.7 \mathrm{lb}$ at room temperature and $1128 \mathrm{lb}$ at $140^{\circ} \mathrm{R}$ Since there are 57 rivets in the control plate which transmit friction loads between the plate and adjacent components, the $1128 \mathrm{lb}$ load represents a load of about $20 \mathrm{lb}$ per rivet. No significant difference between static and dynamic friction was observed during either test.

Inspection of the control plate and other control drum assembly components following each test revealed no damage to ary of the components.

\subsection{CONCLUSIONS}

Since the tests at $140^{\circ} \mathrm{R}$ approximated the most severe differential thermal contractions expected between the control plate and adjacent drum components during reactor operation, the results of the second cryogenic test indicate that with nominal dimensional tolerance conditions the differential contractions that may occur during the NRX - A3 reactor tests should not cause control plate friction forces which could damage the drum components. 


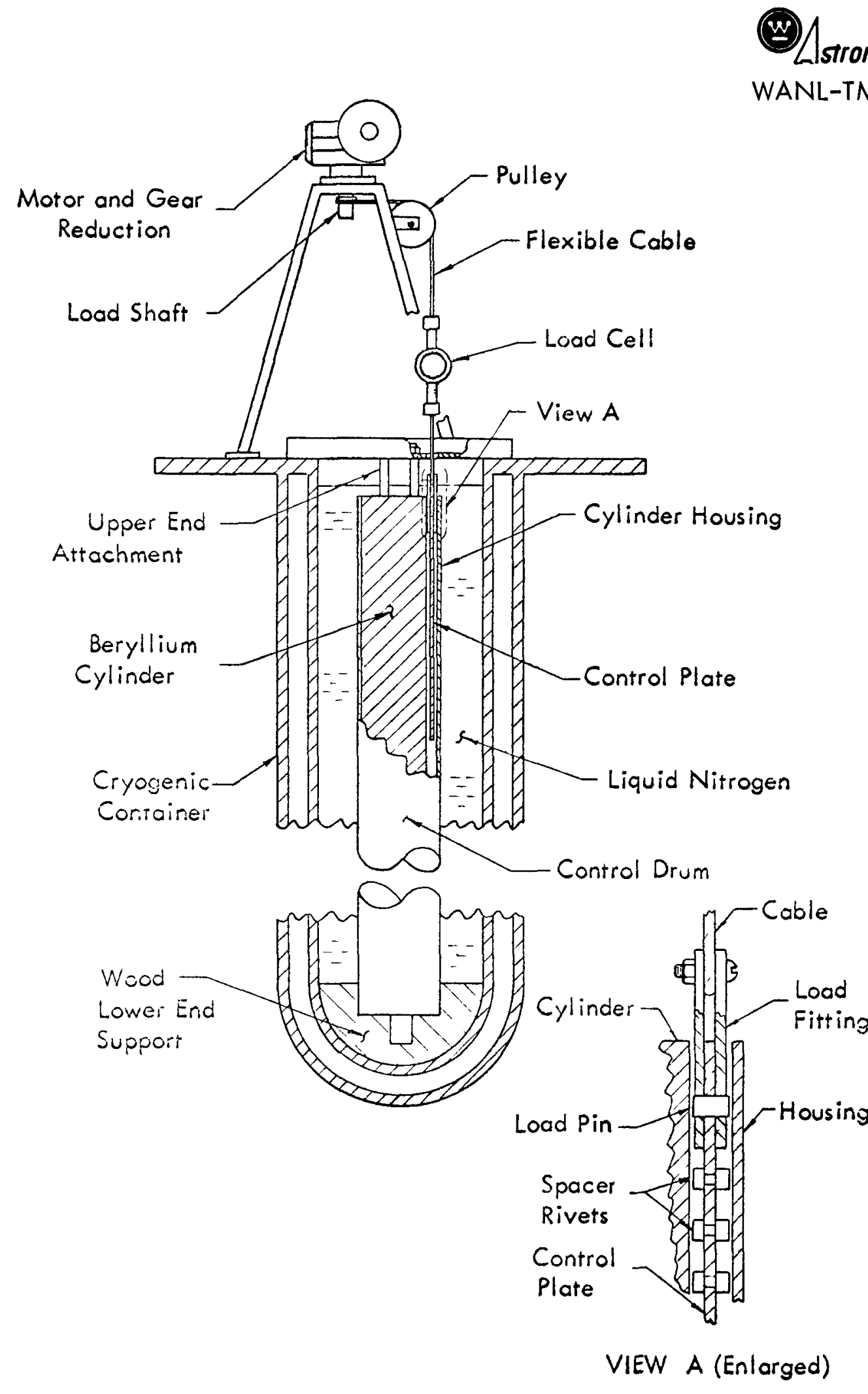

CONTROL DRUM POISON PLATE

FRICTION TEST RIG

FIGURE I 


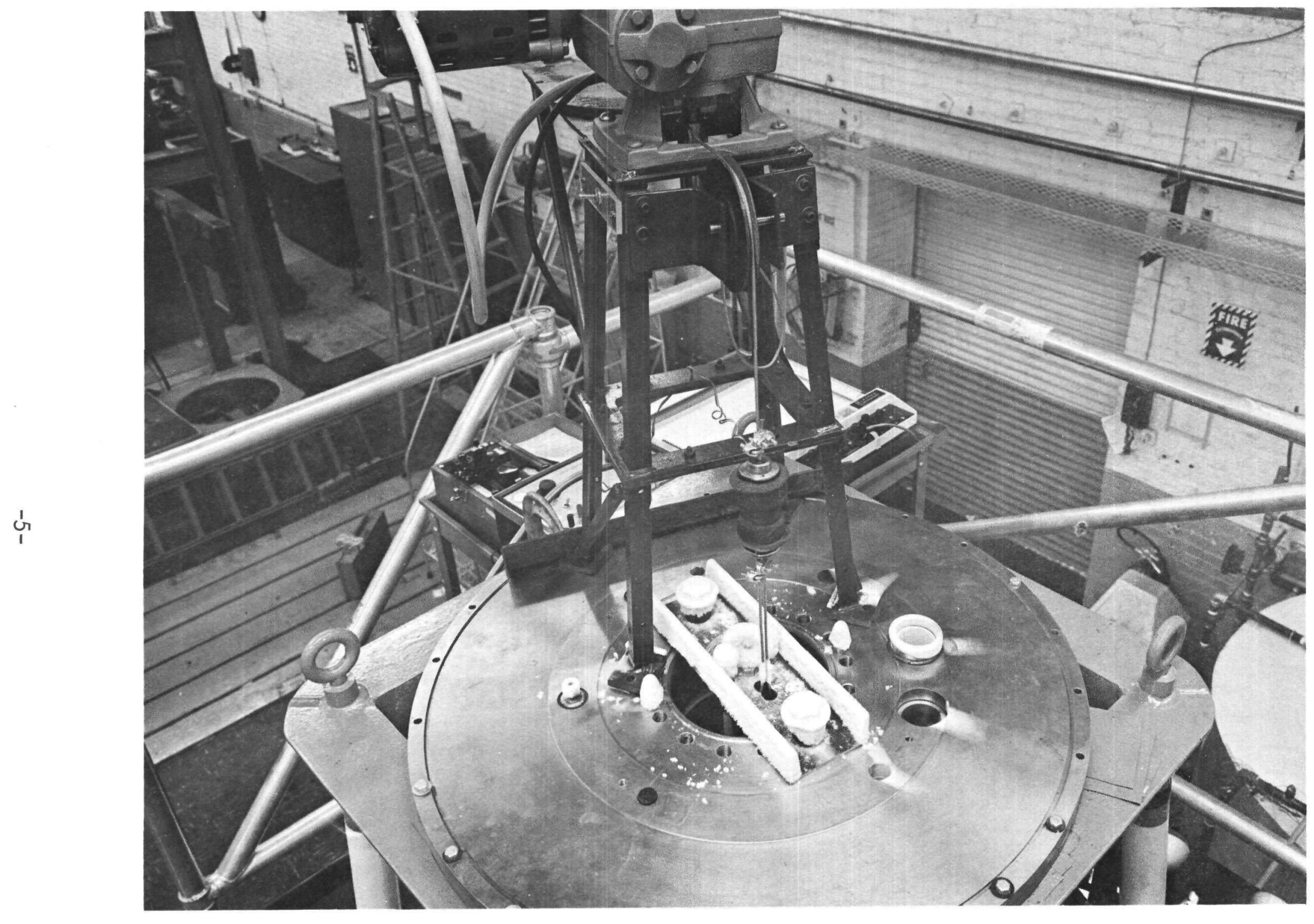

CONTROL PLATE FRICTION TEST SETUP

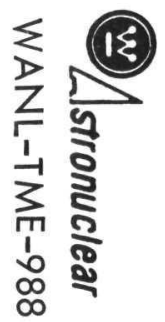

FIGURE 2 


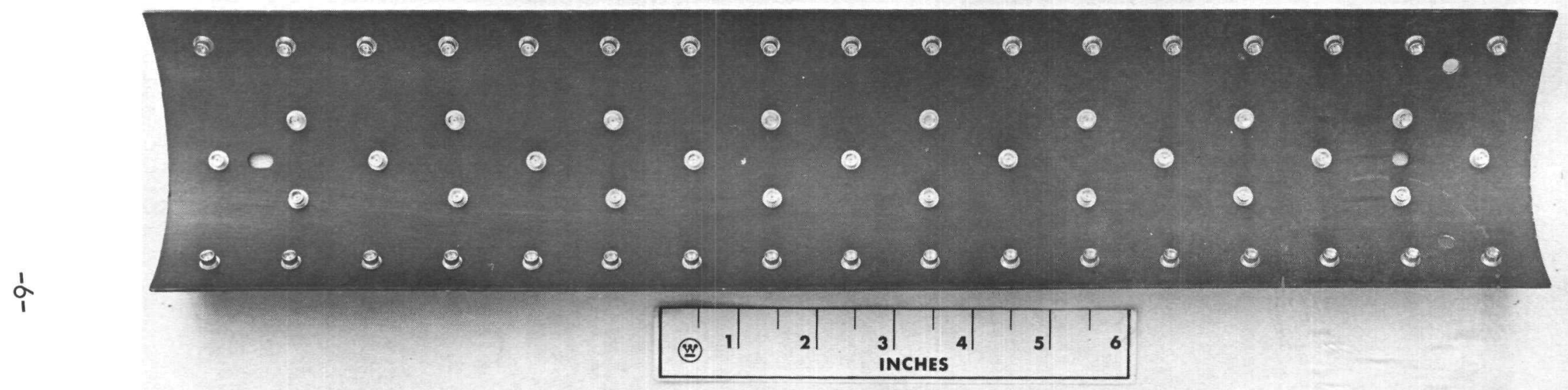

CONTROL PLATE ASSEMBLY SHOWING

SPACER SHIMS UNDER RIVET COLLARS

FIGURE 3

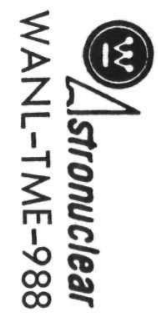

